\title{
Did Philosophy Originate in Greece? An Africanist Response
}

\author{
Matsephe M. Letseka \\ Department of Educational Foundations, College of Education, University of South Africa \\ Email: letsemm@unisa.ac.za
}

\section{Doi:10.5901/mjss.2014.v5n23p1302}

\begin{abstract}
The article aims to subvert the Eurocentric taken-for-granted assumption that philosophy originated in Greece. It shows, first, that long before Greek philosophers such as Socrates, Plato and Aristotle gained prominence, Chinese philosopher Confucius was already an established sage who was dispensing pearls of wisdom on virtue, moral excellence, righteousness, human nature, humane consideration, perfecting oneself, and benevolence. In fact Socrates was only ten years old when Confucius died. Second, the assumption in question fails to account for the historical fact that the Kemetic culture and civilization in present-day Egypt predates Greek civilisation. Indeed Plato visited Egypt around 390 BC to learn about Kemetic culture and civilization. Finally, the paper touches on research on Sage Philosophy in Kenya. The sages were old members of their respective communities who had no prior contact with or exposure to Western formal education and yet they were found to be philosophically rigorous and logical in their engagement and reasoning. All these considerations taken into account, the paper's central view is that philosophy is a bastard, hybrid, grafted, multilinear, and polyglot discipline that cannot be reduced to a single origin.
\end{abstract}

Keywords: origins of philosophy; Greece; Kemetic civilization; Confucian philosophy; sage philosophy

\section{Introduction}

The origins of philosophy (Heidegger, 1956), the nature of philosophy (Priest, 2006; Deleuze \& Guattari, 1994), or whether 'African philosophy' is indeed philosophy or simply a myth (Hountondji, 1996), these are some of the issues that have preoccupied philosophers and continue to be the major bone of contention. This paper grapples with the taken-forgranted view that philosophy originates from Greece. For instance, German philosopher Martin Heidegger (1956:29) is unequivocal that "philosophy originated in Greece". Similarly British philosopher Bertrand Russell (1946) argues that it is the Greeks who invented mathematics, science and philosophy, and speculated freely about the nature of the world and the ends of life, without being bound in the fetters of any inherited orthodoxy. In this paper I challenge such claims for their Eurocentric and inward-looking bias. A few simple questions need to be raised. For instance, what about philosophical speculations from other continents besides Europe? Don't these merit the qualification of philosophy? For instance, Confucius (551-479 BC) died when Socrates (469-399 BC) was only ten years old. This implies that Confucius (Chinese) and Socrates (Greek) philosophized at almost the same era (Liu, 2013; Yu, 2005). What about the Kemet culture and civilization in Egypt, which is known to have predated Greek civilization? (Assante, 1992). But there is more. Odera Oruka's (1990) research among Kenyan sages shows that with absolutely no exposure to formal Western education the sages' conceptual engagement and reasoning were dialectical, rigorous and philosophical.

This is a subversive paper in which my intention is to subvert the Eurocentric idea that philosophy originated in Greece. My starting assumptions are (i) that philosophy cannot be separated from knowledge and other ways of knowing, (ii) that there is no universal one-size-fits-all philosophy for all the peoples of the world, and (iii) that as a result of people's movements and exchange of ideas philosophy has undergone various forms of hybridization that to speak of its single and particularized origin is a misnomer. Given the Afrocentric approach I intend to adopt in this paper I shall argue that African indigenous ways of knowing and systems of thought are not mere concepts, idioms, or cultural expressions, but forms of knowing that have deep philosophical undertones. For instance, when sages in Africa articulate a point of view their articulation is informed by the notion of culture as a knowledge system. By this I mean African systems of thought have their own internal logic, their own sense-making and procedures of argumentation. They are steeped in culturespecific paradigms that are conveyed through local parables (dilotho in Sesotho), folktales (ditsomo in Sesotho), idioms (maele in Sesotho), fables, proverbs, songs, myths and legendary stories.

As mentioned above I shall approach this debate from an Afrocentric perspective. Akiyala (1995: 31) argues that "Afrocentricism's strongest argument is in its call for a counter-hegemonic discourse to break the intellectual and moral 
legitimacy of the Eurocentric bourgeoisie on the mind and lives of the African, Asian, and Latin American world majority". While for comparative purposes I shall refer to Confucian philosophy, my focus is to anchor the debate in an African Weltanschauungen and African traditional systems of thought. First, I shall briefly sketch the claims that philosophy originated from Greece (Heidegger, 1956; Russell, 1946). Second, I shall argue that long before the advent of Greek philosophy Chinese philosopher Confucius was already dispensing invaluable pearls of wisdom on virtue and morality (Liu, 2013; Yu, 2005; Xué, 2005; Yōng, 2005). Third, I touch on the Kemet civilization in Egypt, which is reported to have mastered the use mathematics, physics, and geometry in its architectural designs long before the Greeks. There is evidence that some Greek philosophers, among them Plato, visited Egypt where they learned about Kemet culture and architecture, and took their knowledge and experience back to Greece. In the fourth section I explore the work of Kenyan philosopher Odera Oruka's (1990) among the sages in his country. Oruka's work shows that with no prior exposure to or encounter with tenets of Western philosophy Kenyan sages demonstrated rigorous and logical philosophical reasoning. In the final section I provide some concluding remarks.

\section{Claims that Philosophy Originated in Greece}

The claim that philosophy, like democracy originated from Greece is punted by all and sundry in philosophical circles. It has become 'urban legend' that might pass as 'truth' or 'fact' if it is not challenged and unpacked. For instance, Heidegger (1956:31) writes: "Western European philosophy is in truth, a tautology. Why? Because philosophy is Greek in its nature; Greek, in this instance, means that in origin the nature of philosophy is of such a kind that it first appropriated the Greek world, and only it, in order to unfold". It is Heidegger's (1956:35) contention that "if we truly hear the word and reflect upon what we have heard, the name 'philosophy' summons us into the history of the Greek origin of philosophy". In the same vein, Gritchley (1995) recounts German philosopher Edmund Husserl's claims about the Greek beginnings of philosophy: "we must tell ourselves the story of philosophy's Geek beginning, of philosophy's exclusively Geek beginning - again and again. If philosophy is not Greek we risk losing ourselves as Europeans, since to philosophize is to learn how to live in the memory of Socrates' death". For Husserl, "philosophy speaks Greek and only Greek, which is to say that philosophy does not speak Egyptian or Babylonian, Indian or Chinese and therefore is not Asian or African. Philosophy can only have one beginning and that beginning has to be the Greek beginning". Husserl contends that Europe has a beginning, a birthplace, that is both geographical and spiritual, and the name of that birthplace is Greece. What takes place in Greece, the event that gives birth to our theoretical-scientific culture, is philosophy". Russell (1946: 38) too endorses these views: "almost all the hypotheses that have dominated modern philosophy were first thought of by the Greek". He argues that the Greeks "invented mathematics and science and philosophy". Russell acknowledges that Arithmetic and some geometry existed among the Egyptians and Babylonians, but mainly in the form of rules of thumb. Deductive reasoning from general premises was a Greek innovation.

Deleuze and Guattari (1994:96) posit that "the history of philosophy in Greece must not hide the fact that in every case the Greeks had to become philosophers in the first place, just as philosophers had to become Greek". But Deleuze \& Guattari are quick to caution that "philosophy cannot be reduced to its own history, because it continually wrests itself from this history in order to create new concepts that fall back into history but do not come from it". For them, "philosophy appears in Greece as a result of contingency rather than necessity, as a result of an ambiance or milieu rather than an origin, of a becoming rather than a history, of a geography rather than a historiography, of a grace rather than a nature" (Deleuze \& Guattari, 1994:96-97). The answer to the question "what is philosophy?" has always been that "philosophy is the art of forming, inventing and fabricating concepts" (Deleuze \& Guattari, 1994:2). However, philosophy is more than this given that the "concepts are not necessarily forms, discoveries or products. On the contrary, philosophy is the discipline that involves creating concepts". Deleuze and Guattari (1994:5) argue that "the object of philosophy is to create concepts that are always new". This conception of philosophy is endorsed by Priest (2006:203), who regards philosophers as having the responsibility "for creating new ideas, systems of thought, pictures of the world and its features". It is Priest's (2006:201) contention that "learning philosophy is not simply learning a bunch of facts; it is learning how to critically evaluate people's ideas, including ... one's own ideas and those of one's teachers". For Russell (1946: $\mathrm{xi}$ ), from the earliest times philosophy has not merely been the affair of the schools or of the disputation of a handful of learned individuals, but has been an integral part of the community.

But how sustainable then are the claims that philosophy originated from Greece; is Greek, and therefore does not speak Egyptian or Babylonian, Indian or Chinese and therefore is not Asian or African? A fitting response to this question comes from French philosophers Jacques Derrida (2002) in his book, Ethics, Institutions, and the Right to Philosophy. As Plant (2012:268) points out, Derrida is "wary of any appeal to unsullied philosophical origins". Derrida (2002:10) argues that "philosophy does not have one sole memory. Under its Greek name and in its European memory, it has always been 
bastard, hybrid, grafted, multilinear, and polyglot. We must adjust our practice of the history of philosophy, our practice of history and of philosophy, to this reality, which was also a chance, and which more than ever remains a chance". Derrida (2002:23) cautions that "while keeping in memory this European, Greek origin of philosophy, and the European history of philosophy, [to] take into account that there are events, philosophical events, which cannot be reduced to this single origin, and which mean that the origin itself was not simple, that the phenomenon of hybridization, of graft, or translation, was there from the beginning". For Derrida (2002:40), while philosophy is Greek, and has been Greek, this does "not mean that philosophy in its history is philosophy only to the extent that it refers to the Greek origin". For "even at the origin, in its Greek moment, there was already some hybridization, some grafts, at work, some differential element". It is Derrida's contention that while we should recall the Greek origin of philosophy, we should also "welcome events which have totally displaced this Greek memory ... Egyptian, Jewish, Arabic, and others".

For Dussel (2009: 503), key examples of narratives employing philosophical categories began to emerge in India (subsequent to the Upanishads), in China (from the Book of Changes or I Ching), in Persia, Mesopotamia, Egypt (in texts such as those described as the 'philosophy of Memphis'), in the eastern Mediterranean between the Phoenicians and the Greeks, in Mesoamerica (the Maya and Aztecs or Mexican), in the Andean region the amautas among the Aymaras and the Quechuas, who gave life to Incan civilization. In the same vein Oruka (2002:146) notes that the Greeks borrowed and transformed the ideas of ancient Egypt. Northern Europe and America have done the same to the offerings of Greece. For Oruka, "modern development in philosophy and logic and in other fields of learning, are not an exclusive preserve of Europe or any other culture in which the developments have occurred". Similarly, Husserl (1965: 164) does concede that "philosophy, the science of the Greeks, is not, after all, distinctive of them, something which with them first came into the world. They themselves tell of the wise Egyptians, Babylonians, etc.; and they did in fact learn much from these latter. Today we possess all sorts of studies on India, Chinese, and other philosophies, studies that place these philosophies on the same level with Greek philosophy".

To briefly summarise, in this section I sketched the claims that philosophy originated in Greece. However I have shown that the claim of the Greek origin of philosophy is only contingent rather than necessary. I want to suggest that because of peoples' movement and the eventual sharing and transfer of experiences and cultures philosophy has always undergone a process of hybridization, to the extent that we cannot talk of one single origin. In the next section I venture into the work of Chinese philosopher Confucius, who as mentioned in the introduction above was a practising philosopher long before the advent of Greek philosophers such as Socrates, Plato or Aristotle.

\section{Confucian Philosophy}

By the time Confucius (551-479 BC) died Socrates (469-399 BC) was only ten years old. This piece of history provides evidence that Confucius' engagement with, and contributions to philosophy predate Socrates, Plato and Aristotle. It raises serious doubts on the chronology of the claim that philosophy originated in Greece. It is evident from this piece of history that Confucius was already an established philosopher long before the Greeks Socrates, Plato or Aristotle came to prominence as philosophers. What I want to do in this short section is to briefly touch on a few salient aspects of the Confucian philosophy with a view to rebutting the claims that philosophy originated in Greece.

It is my contention that the thesis that philosophy originated in Greece is flawed, for the simple reason that historically, Confucius was already an established philosopher engaging in teachings about virtue, morality and humane consideration of others long before Socrates (469-399 BC) was born. Zhōngyōng (2005), who has written The Doctrine of the Mean, one of the few books that are regarded as authoritative pieces on Confucius' philosophy, notes that the opening passages of Section 1 of the book: 'Doctrine', introduces a cluster of key terms that feature prominently in Confucius' teachings, such as xing (human nature), dao (centrality or equilibrium), ren (moral excellence, righteousness, perfecting oneself, benevolence). Yu (2005:178-179) argues that the reasons why Confucius is regarded as the founder of Chinese ethics are, first, "he raises the question of the dao of being human, that is, the dao of Heaven as individualized in a human life. This way Confucius introduces the concept of dao (way) as the starting point of his ethical reflection. Second, Confucius uses the concept of ren as a general disposition and ren as a particular trait of character. As a general disposition ren embraces particular character traits, for instance, a quality that makes a man a junzi - 'the gentlemen' or 'the exemplary man'. As a particular trait of character "ren means love or benevolence". Thus "to be ren is to be man" (Yu, 2005:179). Yu (2005) contends that Confucius approaches the issue of ren, or 'human excellence' by appeal to traditional values. There is resonance between Yu's observations here on Confucius' appeal to traditional values and Letseka's (2004, 2013a, 2013b) work on Ubuntu in Southern Africa, which also makes a strong appeal to ground the development of Ubuntu morality among the young people in traditional African norms and values. Confucius' philosophy was based on "a ren (human excellence) - centred dao (way of life). 
Dà Xué (2005:98), who has written The Great Learning, dwells on the impact of Confucius' teachings about virtue. He argues that Confucius taught that "If wealth has come to you contrary to virtue, it will go from you contrary to virtue". Wattles (1987: 123) notes that when Confucius was asked whether there is one maxim that can be practiced throughout one's life, his answer was categorical: "Surely, it is consideration (shu)! What you do not want for yourself, do not do to others". This answer resonates with the Biblical notion of the Golden Rule: "Do unto others as you want them to do to you". But Confucius went further in his teachings by linking the Golden Rule with the notion of ren, which refers to 'manhood', 'kindness' or 'humanity', and "shu or interpersonal care and love" (Wang, 1999: 421).

In summary therefore, in this section I have continued my rebuttal of the view that philosophy originated in Greek. I showed that long before Socrates (469-399 BC) was born, and long before Socrates's successors - Plato and Aristotle gained prominence as Greek philosophers, Confucius was already a fully established philosopher in China dispensing wisdom through his teachings on virtue, moral excellence, righteousness, human nature, humane consideration, perfecting oneself, and benevolence. In the next section I briefly venture into the Kemet civilisation of ancient Egypt, which is known to have predated Greek civilization, and from which the Greek are reported to have learned some invaluable lessons in the critical areas of mathematics, geometry, architecture and philosophy.

\section{Afrocentricity and Kemetic Civilization}

Perhaps I should start by clarifying my understanding of the notion of Afrocentricity. Mazama (2002:232) contends that "embracing Afrocentricity entails being fully and consciously in tune with African metaphysics". In the same vein Lynne (2004:157-158) opines that "Afrocentricity is an African-cantered critique of Eurocentrism that offers a detailed critique of European cultural and ideological domination". In other words, Afrocentricity "is a call to reclaim African and African American history, philosophy and science and to begin the conversation about the ways in which these new discourses can be used for liberatory means". Thus "Afrocentricity is a way of seeing the world; a way of thinking that serves to affirm African people and delegitimize the myths of African inferiority". For Asante (1992:6), "the Afrocentric seeks to uncover and use codes, paradigms, symbols, motifs, and circles of discussion that reinforce the centrality of African ideals and values as a valid frame of reference from acquiring and examining data. Such a method appears to go beyond Western history in order to re-valorize the African place in the interpretation of Africans, continental and diasporan"

Afrocentric scholarship includes the Nile Valley culture of Ancient Egypt. Harkless (2006:5) points out that for the Afrocentric scholars to honour the traditions of 'the ancestors' by calling them by their name, they have substituted the name Kemet for Egypt. She posits that "Kemet ( KMT) is a phonetic rendition of the name that the people called their country....the formal name seems to have been Tawy (The Two Lands) but the commonly used name was Kemet that means the black land along the banks of the Nile River. The people called themselves the Kemites (The Black Ones)". Historically, it can be reasonably argued that when Greek civilization blossomed during Homer's time, millennia before the Mycenae was founded, the Kemet culture in Egypt was at the peak of its development and civilization, culminating in the architectural designs such as the Sphinx of Giza and the pyramids. Evidence from the literature suggests that the Egyptians were already employing the principles of physics and geometry in their architectural designs (Assante, 1992). As Obenga (20004a: 83) points out, Kemetic civilization "achieved fundamental breakthroughs, generated monumental inventions, produced intellectual works of great moral value, explored questions of key philosophical importance".

For Karenga (1988: 411), "a look toward ancient Egypt is the best way of conceiving and building our cultural future". Hilliard III (1992: 20) rightly reminds us that "Ideas about world views (metaphysics), knowledge views (epistemology), and value views (axiology), have been fully developed by African ancestors. They still contain avenues to truths that are worthy guides to mental and spiritual life". In the same vein Obenga, (2004b:31) notes that "in remote times African philosophy was mainly located in the Nile Valley. That is, in Kemet or ancient Egypt, and in Kush (NapataMeroe). Philosophy flourished in Egypt from about 3400 BC to 343BC and in Kush (also known as Nubia or Ethiopia by the Greeks) from about 1000 BC to 625 BC". And lest we forget, Plato visited Egypt around 390 BC. Against the backdrop of this visit Critchley (1995:82) contends that "Egypt invented philosophy, that philosophy was essentially imported into Greece from Egypt, and that Egypt ... was a fount of all philosophical wisdom". And given that "Greece was the subject of colonization and extensive cultural influence from Phoenician traders and mariners....Greek civilization and the philosophy expressed by that civilization were largely a consequence of the influence of near-eastern cultures on the African and Asian continents".

To briefly summarise, what I have attempted to highlight in this section is the fact that before or during the advent of Greek philosophy other, equally advanced civilizations besides Greek civilization were already in existence and flourishing. In this case the Kemetic civilisation of ancient Egypt. The Kemetic civilization has an added impetus in that historical chronicles show that at some point Greek philosopher Plato visited it. We can speculate that Plato's visit was 
part and parcel of a collegial tradition in which scholars visit places of particular reputation in order to learn from the experts in such places and to forge collaborative research partnerships in areas of mutual research interest. In the penultimate section below I touch on a much later scenario, but one which continues my effort to subvert the claims of Greek origins of philosophy. This is the scenario of Kenyan sages, who have no prior contact with Western forms of education but are philosophically rigorous and logical in their engagement and reasoning.

\section{The Sages of Kenya}

Philosophic sagacity is the philosophy practiced by indigenous thinkers or sages. That is, elderly members of the community who may not have had the benefit of Western formal education but are considered critical and independent thinkers who use their critical thought and judgments based on the power of reason and inborn insight rather than the authority of the communal consensus (Oruka, 2002:121). Kenyan philosopher Odera Oruka conducted research on Sage-Philosophy among the sages in his country. The purpose of the research was "to identify individuals of traditional Kenyan breed that are wise either in philosophic (didactic) or in the folk (popular) sense" (Oruka, 1990: 54). The sages were wise old men of the community, who had never in their lives had any encounter with Western formal education, and yet as it turned out, they were rigorous, dialectical and deeply philosophical in their engagements. Oruka (1990:44) cautions though that being a sage does not necessarily make one a philosopher. He points out that "some sages are simply moralists and the disciplined die-hard faithfuls to a tradition. Others are merely historians and good interpreters of the history and customs of their people". That is, "they are wise within the conventional and historical confines of their culture" (Oruka, 1990:44).

Oruka (1990:54) notes that some sages went beyond mere sagacity and demonstrated philosophic capacity. They were rationally critical and "recommended only those aspects of the beliefs and wisdom which satisfy the rational scrutiny". They were "capable of conceiving and rationally recommending ideas offering alternatives to the commonly accepted opinions and practices". For Oruka, such sages "transcended the communal wisdom". How can this feature of Oruka's research be explained? Oruka's (2002:121) answer is simple: "Africans, even without outside influence, are not innocent of logical and dialectical critical inquiry; that literacy is not a necessary condition for philosophical reflection and exposition". And While philosophic sagacity may not be the same as the conventional, long-winded philosophical arguments, "most of it is explicitly expressed in enthymematic form ... a short-cut logical or philosophic argument in the exact sense of philosophy" (Oruka, 2002:122). For Oruka therefore, "philosophic sagacity is individualistic, dialectical, rigorous and philosophical in the western sense" (Oruka, 2002:122). Oruka's research demonstrates that sage philosophy provides evidence that myths, folklores and folk wisdom, which were once regarded as a debased form of philosophy, are equally important in preserving and championing aspects of tradition which were in danger of disappearing due to western influences on the lives of the youth (Presbey, 2007:147).

\section{Conclusion}

What I set out to do in this paper is to subvert the taken-for-granted assumptions that philosophy originated in Greece. Such assumptions were shown to be prominent in the writings of German philosopher Edmund Husserl and British philosopher Bertrand Russell. If anything their views only smack of an ingrained and severe inward-looking Eurocentrism. For then the Greek origin of philosophy is "a story which affirms the link between individuality and universality by embodying that link in either the person of Socrates or by defining the (European) philosopher as the functionary of humanity" (Critchley, 1995:85). I showed, drawing on the work of French philosopher Jacques Derrida ((2002) that the discipline of philosophy is, and has always been a bastard, hybrid, grafted, multilinear, and polyglot. I showed that the thesis of the 'Greek origin of philosophy' overlooks the historical fact that the proponents of Greek philosophy - Socrates, Plato and Aristotle gained prominence as philosophers long after the advent of Chinese philosopher Confucius. I showed that by the time Confucius died Socrates was only ten years old. There is more. Advocates of the 'Greek origin of philosophy' also ignore the fact of the Kemetic culture of ancient Egypt even though history records that Plato actually visited Egypt around 390 BC, which already a flourishing civilization.

\section{References}

Akiyela, M. M. (1995) "Rethinking Afrocentrity: the foundation of a theory of critical Afrocentrity", in Antonia Darder (ed) Culture and Difference: Critical Perspectives on the Bicultural Experience in the United States, Bergin \& Garvey: Westport, Connecticut, pp. 21-39. 
Asante, M. K. (1992) Kemet, Afrocentricity and Knowledge, African World Press: Trenton, New Jersey.

Critchely, S. (1995) "Black Socrates? Questioning the philosophical tradition", Theoria: A Journal of Social and Political Theory, 86:7998.

Deleuze, S. \& Guattari, F. (1994) What is Philosophy? Verso: New York.

Derrida, J. (2002) Ethics, Institutions, and the Right to Philosophy, translated, edited, and with commentary by Peter Pericles Trifonas, Rawman \& Littlefield Publishers: Maryland.

Dussel, E. (2009) "A new age in the history of philosophy: the world dialogue between philosophical traditions", Philosophy \& Social Criticism, 35 (5), 499-516.

Harkless, N. D. (2006) Nubian Pharaohs and Meroitic Kings the Kingdom of Kush, AuthorHouse: Bloomington, Indiana.

Heidegger, M. (1956) What is Philosophy? College \& University Press: New Haven, Connecticut.

Hilliard III, A. G. (1992) "The meaning of KMT (Ancient Egyptian) history for contemporary African American experience", Phylon (19602002), 49 (1/2), 10-22.

Hountondji, P. (1996) African Philosophy: Myth and Reality, Second Edition, Indian University Press: Bloomington.

Husserl, E. (1965) Phenomenology and the Crisis of Philosophy: Philosophy as Rigorous Science and Philosophy and the Crisis of European Man, Harper \& Row Publishers: New York.

Karenga, M. (1988) "Black Studies and the Problematic of Paradigm: The Philosophical Dimension", Journal of Black Studies, 18 (4), 395-414.

Letseka, M. (2014) "Ubuntu and Justice as Fairness", Mediterranean Journal of Social Sciences, 5 (9), 544-551.

Letseka, M. (2013a) "Educating for ubuntu: lessons from Basotho indigenous education", Open Journal of Philosophy, 3 (2), $337-344$.

Letseka, M. (2013b) "Anchoring Ubuntu morality", Mediterranean Journal of Social Sciences, 4 (3), 351-359.

Liu, Q. (2013) "Emotionales versus rationales: a comparison between Confucius' and Socrates' ethics", Asian Philosophy, 23 (1), 86-99.

Lynne, M. (2004) "Inserting the race into critical pedagogy: an analysis of race-based epistemologies", Educational Philosophy and Theory, 36 (2), 153-165.

Mazama, M. A. (2002)"Afrocentricity and African Spirituality", Journal of Black Studies, 33 (2), 218-234.

Obenga, T. (2004a) African philosophy: the Pharaonic Period, 2780-330 B.C, Popenguine: Senegal.

Obenga, T. (2004b) "Egypt: Ancient History of African Philosophy", in Kwasi Wiredu (ed) A Companion to African Philosophy, Blackwell Publishing: Malden, California, pp.31-49.

Oruka, H. O. (2002) "Four trends in current African philosophy", in Philosophy from Africa, 2nd edition, edited by P.H. Coetzee \& A. P.J. Roux Cape Town: Oxford University Press, pp.120-124.

Oruka, H. O. (1990) Sage Philosophy: Indigenous Thinkers and Modern Debate on African Philosophy, Masaki Publishers: Nairobi.

Plant, B (2012) "This strange institution called 'philosophy': Derrida and the primacy of metaphilosophy", Philosophy and Social Criticism, $38(3$,$) 257-288.$

Presbey, G. M. (2007) "Sage philosophy: criteria that distinguish it from ethno-philosophy and make it a unique approach within African philosophy", Philosophia Africana, 10 (2):127-160.

Priest, G. (2006) "What is philosophy?" Philosophy, 81:189-207.

Russell, B. (1946) History of Western Philosophy, George Allen \& Unwin: London.

Wang, Q. J. (1999) "The Golden Rule and Interpersonal Care: From a Confucian Perspective", Philosophy East and West, 49 (4), $415-$ 438.

Wattles, J. (1987) "Levels of Meaning in the Golden Rule", The Journal of Religious Ethics, 15 (1) 106-129.

Xué, D. (2005) The Great Learning, translated by Gregory C. Richter, Truman State University: Kirksville, Missouri.

Yōng, Z. (2005) The Doctrine of the Mean, translated by Gregory C. Richter, Truman State University: Kirksville, Missouri.

YU, J. (2005) "The beginning of ethics: Confucius and Socrates", Asian Philosophy, 15 (2), 173-189. 